\title{
Specific Philosophical and Legal Approaches to Understanding the Nature of the State-legal Enforcement
}

\author{
Alexey Annenkov \\ Institute of Law and Management \\ Tula State University \\ Tula, Russia \\ E-mail: lex97531@mail.ru
}

\begin{abstract}
The article considers the essence and the framework of understanding the state-legal enforcement, in particular, through cognition of the generic category of "coercion." An attempt is made to study this phenomenon in the sense of the philosophy of law and the philosophical and legal reflections with account of the scientific positions taken by the representatives of the German classical philosophy of Immanuel Kant and Georg Wilhelm Friedrich Hegel, phenomenological and axiological approaches.
\end{abstract}

Keywords-coercion; state-legal enforcement; state enforcement; philosophy of law; phenomenology of law; axiology of law; philosophy of state enforcement

\section{INTRODUCTION}

The notion of -state-legal enforcement" has primordial, methodological significance for the world of law. As a legal phenomenon, traditionally, it is in the orbit of attention of the scientists from both the field of theory of state and law, and from the field of the branch legal sciences. This is due primarily to its properties and potential, as well as due to the modern law reforming in Russia, and, specifically, regarding the changes in the legislative base governing the state enforcement proper.

The state-legal enforcement is a social-and-legal phenomenon which has been drawing the attention of the researches from the different areas of scientific knowledge over a long period of time owing to its complexity and multidimensionality, diversity of its manifestations and the ability to solve a widest range of tasks in the matter of state and public administration.

The enforcement is most often used to describe the directed action which has the aim of making someone do something or do not do something against the will of the actor. The term to force" means to make someone do something; to forcefully impel some action" [1].

The enforcement is one of the universal operating methods (modi operandi) of any kind of social power, for execution of any form of social administration [2]. It exists among all sorts of human living together and is an essential element of social organization. Before the formation of classes in the society, it was based on the authority of the elders, the tribal chiefs and the likes, in the graded societies on the authority of the State. Consequently, the enforcement is fundamentally linked to the statehood, the state power and determines the quality thereof [3]

At the same time, S.S. Alekseev's assertion that the state enforcement alone is not a legal property appears to be true. [4] To a greater degree it shows the connection between the law and the state. In this respect, the coerciveness expresses only the possibility of imposing the state coercive measures [4].

The regulatory control within the confines of any organized society implies the enforcement without which the normativity gets blurred, the framework, the boundaries for behavior are disappearing and there is nothing left from the extent of conduct." [5] In this sense, the enforcement represents a moment of actual implementation, of real effect of the law; it means that the law itself has come into reality, that it takes real effect and that the law is power. [6]

And it's natural that there is a very close relationship between the law and the state. It's from the state that the intrinsic feature and the distinction of the law, which is the ruling power, the support by the authoritative enforcement, can be derived. On the other side, the state, while executing the authoritative enforcement, shall not go beyond the scope of the legal field and only in this regard we can speak of the state-legal enforcement.

However, the enforcement exists in the society not because there are legal norms providing for its implementation, but because it is necessary for protection of the corresponding social relations, the subjective legal rights of the persons whose interests can suffer from wrongdoings and undesirable phenomena of legal nature [7].

The very notion of -enforcement" is characterized by multidimensionality of understanding and meaning, because it constitutes a complex social and legal formation that can be studied from the different worldview positions. 
In the majority of main fields of philosophical and philosophical-and-legal inquiry the enforcement is given a considerable attention, though a common understanding of what the enforcement entails, what is its role, what is its direction and what are its means of influence on the society has not yet been reached.

Some authors while defining the enforcement use the notion submission" as a fundamental idea. Thus, in particular, the enforcement is quite often defined as the process the final result of which can be the state of submission," [8], bringing a person to submission... against his will in order to use his capacities for reaching certain public or personal goals," [9], -ne of the ways (methods) that constitute the state of submission (being subordinate)" [10].

Other scientists, while drawing, by all appearances, on active and willful nature of the enforcement, define it as the purposeful actions aimed at the limitation of an individual's freedom of doing something that he, in accordance with his free will, wants to do. [11]

Considering the nature of the state-legal enforcement, it is necessary to refer, first of all, to analysis of specific philosophical and philosophical-and-legal approaches to comprehending its essence.

\section{THE STATE-LEGAL ENFORCEMENT FROM THE STANDPOINT OF THE GERMAN CLASSICAL PHILOSOPHY}

The analysis of the content and the scope of the notion of -state-legal enforcement" from the standpoints of the German classical philosophy, is, most notably, connected with the scientific works of I. Kant and G.W.F. Hegel.

In the framework of his philosophy, I. Kant addressed among other things the problem of understanding the enforcement. One of the main achievements of his theory is the category of law enforcement. $\mathrm{He}$ thought that everything that is wrong is a hindrance of freedom, according to universal laws; and compulsion or constraint of any kind is a hindrance or resistance made to freedom. Consequently, if a certain exercise of freedom is itself a hindrance of the freedom that is according to universal laws, it is wrong; and the compulsion of constraint which is opposed to it is right, as being a hindering of a hindrance of freedom, and as being in accord with the freedom which exists in accordance with universal laws. Hence, according to the logical principle of contradiction, all right is accompanied with an implied title or warrant to bring compulsion to bear on any one who may violate it." [12]

However, the forms of enforcement, which is inherent both in the law, and in other social regulators, for example, the morals, differ substantially from one another. I. Kant pointed out the internal (moral) coercion and external (legal) coercion (enforcement). The moral coercion is an internal self-coercion which arises due to the confrontation of a person's internal moral and ethical imperative and the existing inclinations, and it was determined by I. Kant as a self-coercion based on free will." The legal coercion puts a person in an absolutely different situation, because in this case the coercion affects a person from the outside. The incentive for a person to fulfill a required action under coercion is the threatening punishment, the fear of legal liability. [12] Thus, I. Kant singles out one more difference between the moral and legal coercion: the internal selfcoercion does not involve the punishment sanctioned by the law, and a person is not guided by the incentive of fear in front of him, whereas the legal coercion implies such incentive.

We think that the relationship between the enforcement and the social regulators (the morals, the law) is expressed by the fact that they cannot exist without coercion. Compliance with the norms, as the model of conduct, comes with subjecting the will of a person under the action of either internal coercion, or external one.

I. Kant meant by coercion any restriction of freedom of one individual by the manifestation of another individual's will [13]. Freedom is the possibility of a person to make his life choice on his own, provided that the determined boundaries are observed and another person's corresponding freedom is not violated. For the purpose of human existence in the society, people's relations must be governed by the law, which, in fact, puts the limits on the freedom of one group of people in relation to the freedom of the others. It means that each person is free to an extent compatible with the freedom of another person. Here, the coercive power of the positive law, providing for the reasonable definition of the boundaries and the respect for freedom of the whole society, is reasonably revealed. This reflects the particular value for legal understanding of the coercion - the rights, the freedoms and the coercion are unified.

I. Kant distinguishes three categories of the law: the natural law i.e. the set of moral norms, or principles imposed by the practical reason; the positive law based on the legislator's will which must correspond to the natural law i.e. the requirements of categorical imperative but, at the same time, it must draw on the force of coercion; the justice i.e. a combination of an individual's claims not supported by coercion [12].

I. Kant has formulated the law of reciprocal and equal coercion which is compatible to the freedom of each person guided by the principle of the universal freedom [14]. The coercion becomes a means for distribution of personal freedom in order to apply the justice [15].

I. Kant wrote also: $\Psi$ can be forced by others to commit certain acts intended as the means for the specific ends, but I can't be forced by others to have a particular intention, only I can do something on the basis of my intention" [16]. Under coercion the original direction of the actor's activities changes, these activities transform from the means of satisfying one's personal needs into the means of satisfying the needs of the coercing person, however, it does not involve the change of purpose.

G.W.F. Hegel laid out his peculiar understanding of coercion. It can be noted that he considers the state and the law in the framework of the philosophy of spirit. The right is understood as a form of appearance of reasonable spirit, the 
essence of which is part of the world of freedom. The philosophical-and-legal perception of coercion is based on the question of free existence of an individual. G.W.F. Hegel wrote that the spiritual nature of a human being presupposes the presence of personality for which cause no person must be forced to doing something apart from bringing the end to the violence caused to another individual by such person.

The process of coercion is described by G.W.F. Hegel in the following way: Something is connected to a person's present existence as being its condition, so if the person wants to keep one thing, then he has to put up with another thing. And given that the person's present existence depends on the external things, so he can be brought to dependence precisely on the part of his present existence." The coercion according to Hegel is a willful act, and it's depending on the actor itself whether the person submits to this act or not [17].

The state is understood by G.W.F. Hegel as an organized enforcement limited by various restraining factors. It is the moral idea in effect" without the medieval violence (coercion) provided with a theist substantiation. The state enforcement is considered as a right to a sanction, and the coercion in general is an active reaction of will to any kind of impact. That is why Hegel's state accepts the sanction and the enforcement in general, but rejects only its barbarian forms. According to G.W.F. Hegel, the state represented by the government enforces the rights. But at the same time, the usage of force by the state is limited. Only the military transformation of the state that produced an impact on the state regime, reinforces the action of public authorities and begets the unlimited intrusion of the state upon the rights of an individual and the civil society, that is the right of public total coercion. [17]

The significance of G.W.F. Hegel's position consists in the actual importance of definition of the boundaries of enforcement, in particular, in terms of non-admittance of abusing the right of enforcement. His concept is one of the basic concepts in keeping with substantiation of necessity of the state enforcement. The very category -enforcement" is presented clearly by the scientist, the main features of this category are specified.

\section{PhenOMENOlOgiCAL PRINCIPLES OF THE STATE- LEGAL ENFORCEMENT}

Analyzing the state-legal enforcement in terms of phenomenological approach implies using the phenomenological instruments in relation to the analyzed notion, its real and ideal structure. Therein the real" and the idea" in the state-legal enforcement are not opposed to each other, but are considered in indissoluble unity, because we handle the real state-and-legal phenomenon and it is through reality that its essence is revealed.

The state-legal enforcement shall be considered as part of legal reality and, at the same time, as a phenomenon possessing its terminology and its normative ideal framework (underlying principles and establishment of rights), through which appears its ideal essence, precedent over the versions of the phenomenon under consideration, possessing certain specificity, preconditioned variability of legal systems of the past and the present. It is through the ideal framework, clear of spatial-temporal, psychological, historical, cultural and social peculiarities as a result of proceedings of an epoch that comes the reductive cognition of the state-legal enforcement. In this setting, the eidos of the state-legal reinforcement can be expressed by means of legal capacities, the legal faculty of the state as an ideal mainstay which is intersubjective and objectified. At the same time, the legal faculty is considered as a foundation of the law.

In the view of the phenomenological understanding of the state by N.N. Alekseev, both the state itself, and the state-legal enforcement, are the normative fact (one of the kinds of the normative facts (legal sources)). The normativity of the analyzed phenomenon is related to the ideal structure of the law and, first of all, to the actors and the values. The empirical existence of the state-legal enforcement implies a certain ideal, normative framework, thanks to which the exercise of authority by the state acquires the properties of unity and wholeness. In this case the submission to the state authority is not the consequence of the actual unavoidability, but is a result of acceptance of reasonable necessity issuing from belonging to the some whole." [18]. In this regard, the loss of wholeness as a property in the state-legal enforcement leads to destruction of the state or conversion to despotism.

\section{AXIOLOGICAL PRINCIPLES OF THE STATE-LEGAL ENFORCEMENT}

The axiological analysis of the state-legal enforcement allows for considering this phenomenon as a value which is the generally meaningful principle of the activities, the functioning and the existence of the society, the state, the axiologically reducible knowledge of which is the convergence of all multitude of forms of social-and-cultural differences in the manifestation of the phenomenon into the organic unity. Whereas, the separate manifestations of the state-legal enforcement in the framework of the legal reality shall be considered as welfare.

F.N. Fatkullin and L.D. Chulyukin, while studying the social value and the efficiency of the legal norm, wrote that: In the final reckoning, all that is reasonably necessary and meaningful for the progress in the corresponding area of a human life is valuable." This is also true in relation to the analysis of the phenomenon of the state-legal enforcement [19].

The axiological approach to analyzing the state-legal enforcement enriches the understanding of modern political and legal processes in the area of the state control, allows us to recognize the axiological component of the analyzed phenomenon, its role in establishing the stability in the society and the state, social equilibrium, harmony in the existence of the social, political and legal system.

The cognitive potential of the axiological approach to the state-legal enforcement is expressed through overcoming the narrow scope of the normativism and the statism, the onesided approach to getting the insight into the legal phenomena. 
It is inevitable that the situation occurs when any system of the norms sanctioned by the state authority claims to be the law, and any organized society that need to be legitimized and exercising the organized violence claims to be the state." [20] The value-based approach to the law provides an opportunity to avoid defining the specified state of the society as the legal status. The coercive measures taken by the state shall be lawful, based on the general values and principles of the law, and shall not be perceived as a manifestation of the random instrumental violence.

This being the case, the value-based aspect is important here not only in relation to the extreme situations," when the society exists and the state acts on the basis of the ideology opposing the humanistic ideals (racism, extremism, genocide, fascism, etc.) but also when defining the vector of developing the relationship between a personality, the society and the state in future, including the legal sphere.

In this connection and on the basis of the concept established by V.A. Nudko, the state-legal enforcement shall be considered as a specific social phenomenon, a certain expression of social relations and the normative-evaluative side of the public consciousness. [21]

Besides, the state-legal enforcement may be viewed as a value-based relationship in the system -subject-object." The value of the phenomenon is revealed through expressing the subject's relation to the object. Viewing the value as a special quality of interrelationship between the object and the subject is against such approach.

The value of the state-legal enforcement which is specific for a particular state (preconditioned by the historical and geographical development) is projected towards welfare and represents a version of the highest degree of the social regulation and consolidation.

In today's environment, the subject matter of axiological orientations in the theoretical legal science, on the whole [22], and, in particular, concerning the state-legal enforcement - the set points and legal values determining its essence, direction and meaning is revealed through the substantiating the fundamental and first-order ideas, such as freedom, justice, equality and humanism, taken as a foundation.

It must be noted, that the specifics of the values contained in the notion of the state-legal enforcement and the complexity of its identification consists in the fact that the manifestations of the analyzed phenomenon, as the values themselves, take multiple forms in different societies, and, as a rule, they reflect the deep civilizational differences.

\section{CONCLUSION}

Thus, the coercion is the category expressing the phenomenon of the material reality comprising many things. It is an indispensable element of each human society, and, the state-founded society, in particular. In this regard, the one-sided perception of this notion shall be deemed not quite justified, because this category is characterized not only by a rather complex intrinsic meaning, but also by the multidimensionality of its manifestation within the sector.

The philosophical and legal premises for cognizing the state-legal enforcement are the following provisions: the coercion is the submission of the free will; the coercion is exercised in order to make it possible to give freedom in equal measure to each member of the society; in this setting, it is required to establish the boundaries of enforcement not allowing for impairment of the rights of other people and putting someone's interests to a preferential position; the enforcement is the attribute of the state and the law; legal relations cannot be held without the possibility of applying the enforcing measures.

The enforcement as a phenomenon of the social life cannot be eliminated and the degree of democratism, social justice, civil freedom and formal equality in the society depend on the role of the enforcement in formation of legal, state and public institutions.

The results obtained in the course of the research serve as a theoretical foundation for solving the relevant scientific and practical issues of studying the nature and the essence of the state-legal reinforcement.

Further research of the described theoretical legal problem is advised to be conducted with account for the pluralism of the philosophical and legal approaches and through integrative perception of the analyzed methodologically meaningful concept.

\section{REFERENCES}

[1] Ushakov D.N. The Explanatory Dictionary of the contemporary Russian language. M.: Adelant Publishing House, 2013. 800 pages.

[2] Baitin M.I. The Essence of the law. Saratov. SGAP (-Saratov State Academy of Law"), 2001. 416 pages.

[3] Sevryugin V.E. The questions of the administrative law: study guide /Tyumen Higher School of the Russian Federation Ministry of Internal Affairs, Tyumen State University — Tyumen, 1994. 208 pages.

[4] Alekseev S.S. The Social value of the law in the Soviet society. M.: Yuridicheskaya Literatura (-Eegal Literature" Publishing House), 1971. 223 pages.

[5] Bratus S.N. The Legal liability and legitimacy. M.: Yuridicheskaya Literatura (Eegal Literature" Publishing House), 1976. 216 pages.

[6] Ilyin I.A. The notions of the law" and the force" (Methodological analysis experiment. Collected works in 10 volumes. Volume 4. M. Russkaya Kniga (-Russian Book" Publishing House), 1994. 216 pages.

[7] Seregina V.V. The legal regulation as one of the factors of conditionalism of the state enforcement // The legal regulation: questions of efficiency, legitimacy, justice: Collection of works of the International Science Conference (Voronezh, June 2-4, 2016) / [editorial board: Denisenko V.V. (responsible editor), Belyaev M.A.]. - Voronezh: NAUKA-UNIPRESS Publishing House, 2016. 624 pages.

[8] Fedorov V.P. The Enforcement in the system of the socialist administration: thesis, Candidate of philosophical sciences: 09.00.13 / V.P. Fedorov. - L., 1975. 175 pages

[9] Social administration: Dictionary / under the editorship of V.I Dobrenkov, I.M. Slepenkov. — M: MSU Publishing House, 1994. 208 pages. 
[10] Ardashkin V.D. On the enforcement according the Soviet law // Sovetskoe gosudarstvo i pravo (-The Soviet state and the law"). 1970. No. 7.

[11] Chukin S.G., Salnikov V.P., Balakhonsky V.V. The philosophy of the Law: course book/ under the general editorship of V.P. Salnikov, G.N. Khon. - M.: IMTS GUK MVD Rossii Publishing House (fnformation and Methodological Center of the Central Personnel Administration of the Ministry of Internal Affairs of Russia"), 2002. 240 pages.

[12] Kant I. Metaphysics of Morals in two sections // Kant I. Critique of practical reason. SPb.: Nauka Publishing House, 1995. 528 pages.

[13] Abdulaev M.I. The Law and State Doctrines of Kant // Pravovedenie (世egal Science"). 1998. No. 3.

[14] Tumanov A.A. The Substantiation of Freedom, Law and Legal Justice in the critical philosophy of I. Kant: thesis, Candidate of philosophical sciences: 09.00.13 / A.A. Tumanov. Murmansk, 2007. 258 pages.

[15] History of political and legal doctrines, the: course book/ V.S. Nersesyants [et al] ; under the general editorship of V.S. Nersesyants. — M. INFRA-M Publishing House, 1996. 736 pages.

[16] Kant I. Metaphysics of Morals in two sections. Section Two Metaphysical principles of virtue // Collected works in 6 volumes. Volume 4. - M.: Mysl Publishing House, 1965, Section 1. 544 pages. Section 2. 478 pages.

[17] Puchnin A.S. The enforcement and the law: thesis, Candidate of legal sciences: 12.00.01/ A.S. Puchnin. Tambov, 1999. 234 pages.

[18] Deforges I. The philosophy of the law according to N.N. Alekseev: thesis, Candidate of philosophical sciences: 09.00.03/ I. Deforges. M., 2006. 169 pages.

[19] Fatkullin F.N. The Social value and the efficiency of the legal norm/ F.N. Fatkullin, L.D. Chulyukin. - Kazan: The Publishing House of the Kazan University, 1977. 119 pages.

[20] Permyakov Yu. E. Lectures on the philosophy of the law / Yu. E. Permyakov. - Samara.: The Publishing House of the Samara State University, 1995. 120 pages.

[21] Nudko V.A. The plurality of definitions of the notion of talue" / V.A. Nudko // Voprosy gumanitarnykh nauk (The Questions of Human Sciences"). 2005. No. 3.

[22] Martyshin O.V. The Question of values in the theory of the state and the law / O.V. Martyshin// Gosudarstvo i pravo (The State and the law"). 2004. No. 10 